\title{
Primary thyroid tuberculosis: a rare etiology of hypothyroidism and anterior cervical mass mimicking carcinoma
}

\author{
Tuberculose tireoidiana primária: rara etiologia de hipotireoidismo \\ e massa cervical anterior mimetizando carcinoma
}

Bradley Paulino da Silva', Erico Gurgel Amorim', Elizabeth João Pavin', Antonio Santos Martins², Patrícia Sabino de Matos $^{3}$, Denise Engelbrecht Zantut-Wittmann'
1 Disciplina de Endocrinologia, Departamento de Clínica Médica, Faculdade de Ciências Médicas, Universidade Estadual de Campinas (Unicamp), Campinas, SP, Brasil 2 Disciplina de Cirurgia de Cabeça e Pescoço, Departamento de Cirurgia, Faculdade de Ciências Médicas, Unicamp, Campinas, SP, Brasil

${ }^{3}$ Departamento de Anatomia Patológica, Faculdade de Ciências Médicas, Unicamp, Campinas, SP, Brasil tial diagnosis of hypothyroidism and anterior cervical mass. Arq Bras Endocrinol Metab. 2009;53(4):475-8.

Keywords

Thyroid tuberculosis; hypothyroidism; anterior neck mass; thyroidectomy

\section{RESUMO}

Objetivo: A tuberculose tiroidiana ocorre raramente. O hipotireoidismo decorrente da destruição tiroidiana é um relato raríssimo. Nosso objetivo foi descrever o caso de paciente com tuberculose tiroidiana primária e ressaltar a raridade e a importância da doença. Relato do caso: Mulher, 62 anos, apresentando massa cervical extensa há quatro meses, associada à inapetência, à perda de peso, à disfonia e à disfagia. A investigação laboratorial mostrou hipotireoidismo primário. Ultrassonografia: lesão expansiva em lobo esquerdo, envolvendo musculatura subjacente. Tomografia computadorizada: massa heterogênea com centro necrótico, $13 \mathrm{~cm}$ de diâmetro. Biópsia por aguIha fina: material serossanguinolento. Cirurgia: tireoidectomia, dissecção radical à esquerda e traqueostomia protetora. Exame anatomopatológico: processo inflamatório crônico granulomatoso com áreas de necrose caseosa e comprometimento linfonodal. Baciloscopia tiroidiana positiva. Ausência de comprometimento pulmonar. A paciente foi tratada com drogas antituberculosas. Conclusões: Tuberculose tireoidiana não é frequente, mas deve ser considerada como diagnóstico diferencial de hipotireoidismo e massa cervical anterior. Arq Bras Endocrinol Metab. 2009;53(4):475-8.

Correspondence to:

Denise Engelbrecht Zantut

Wittmann

Disciplina de Endocrinologia, Departamento de Clínica Médica, Faculdade de Ciências Médicas, Unicamp

PO Box 6111

Rua Tessália Vieira de Camargo, 126 - Barão Geraldo

13084-971 - Campinas, SP, Brasil

zantutw@fcm.unicamp.br

Received in Dec/7/2008

Accepted in Mar/3/2009

\section{INTRODUCTION}

$\mathrm{T}$ uberculosis $(\mathrm{TB})$ has been described in many parts of the body, but the involvement of the thyroid gland is rare. The first description of thyroid TB in the literature was reported by Lebert, in 1862, in a patient with miliary TB. In 1893, Bruns described primary TB 
of the thyroid gland with cervical lymph node involvement, without pulmonary disease $(1,2,3)$. The scientific literature reports about 200 cases of $\mathrm{TB}$ in the thyroid, most with primary focus outside the thyroid gland $(4,5)$.

The TB bacillus reaches the thyroid through hematogenous and lymphogenous dissemination or directly by cervical lymphadenitis. The clinical presentation is variable, with subacute or chronic thyroid enlargement, but most cases manifest itself as a nodule or caseous abscess (6). The diagnosis can be made by baciloscopy (Ziehl-Neelsen staining for acid-fast bacilli) and culture of material collected through a fine needle aspiration (FNA) or histopathologic exams $(3,6,7)$.

We described the case of a patient with primary thyroid TB associated with hypothyroidism, cervical lymph node and thyroid mass mimicking thyroid carcinoma, without lung injury.

\section{CASE REPORT}

Female patient, 62 years old, presented with a fourmonth history of progressively growing painless left cervical mass, anorexia, $6 \mathrm{~kg}$ weight loss, dysphonia and dysphagia. Past medical history included diabetes mellitus and hypertension in the last eight years, and a primary hypothyroidism in the last three months. Medications included metformin, captopril, NPH insulin, AAS and L-Thyroxin $(50 \mu \mathrm{g} /$ day $)$. She denied family history of thyroid disease, TB or contact with TB patients.

Physical examination showed good general condition with no fever, and normal cardiovascular and pulmonary findings. Head and neck examination revealed a $10 \times 4 \mathrm{~cm}$ solid and hard left cervical mass in levels III and IV, in continuity with left lobe of the thyroid gland. Laboratory evaluation: $\mathrm{TSH}=10.3 \mathrm{IU} / \mathrm{mL}$ $(\mathrm{VR}=0.41-4.5)$, free thyroxin $\left(\mathrm{FT}_{4}\right)=0.96 \mathrm{ng} / \mathrm{dL}$ $(\mathrm{VR}=0.9-1.8)$, negative antithyroperoxidase (TPOAb, $\mathrm{VR} \leq 76 \mathrm{IU} / \mathrm{mL}$ ) and antithyroglobulin antibodies (TgAb, VR $\leq 120 \mathrm{IU} / \mathrm{mL}$ ). Head and neck endoscopy was normal, except for left vocal cord paralysis. Neck and thyroid ultrasonography revealed enlarged thyroid lobes (more pronounced in the left), and multiple enlarged left cervical lymph nodes with sternocleidomastoid muscle involvement and anterior left submandibular gland displacement. The cervical tomography showed a left neck mass of coalescent nodes, measuring $13 \times 4 \times 4 \mathrm{~cm}$, involving levels IB, II, III and IV left, in continuity with the sternocleidomastoid muscle and the left lobe of the thyroid and with mediastinal extension. Chest radiography and esophagoscopy were normal.

The FNA, done three times, was non-conclusive, with no evidence of malignant cells.

Despite the negative initial biopsy and frozen section, and with the presumptive diagnosis of malignant thyroid tumor based in the patient's medical history and in the surgical findings, the patient was submitted to total thyroidectomy and left radical neck dissection. Right and left upper parathyroid glands were identified and preserved as well as both recurrent nerves. However, a protective tracheotomy was felt to be necessary. Surgical findings included a bilateral hard thyroid mass and multiple involved left neck nodes level I thru VI, fixed to sternocleidomastoid muscle and internal jugular vein at levels III and IV.

The pathological examination showed little residual thyroid tissue, with extensive area of white tissue, elastic, joined to the soft tissue around and multiple yellowish nodules. The optical microscopy showed chronic granulomatous inflammatory process with areas of caseous necrosis (Figures $\mathrm{IA}$ and $\mathrm{IB}$ ) and calcification, compatible with TB etiology. The cervical lymph nodes at level I were affected and the cytological smear presented acid-fast bacilli. The patient was treated with rifampin, isoniazid and pyrazinamide for nine months. The HIV serology proved negative. There was no clinical recurrence in the following two years.

\section{DISCUSSION}

The diagnosis of TB in the thyroid is rarely performed by preoperative clinical suspicion (2). The clinical presentation can mimic cancer, similar to the present report, bleeding or abscess in the thyroid and, in general, the diagnosis is made after biopsy $(3,6)$. In postmortem studies, TB in the thyroid was recognized in 0.003 to $0.1 \%$ of the cases. Graham (1932), found 21 cases of thyroid TB among the 20,758 partial thyroidectomy specimens $(2,3)$. However, thyroid foci of TB can happen in $14 \%$ of miliary TB $(8)$.

The cause of the rarity of thyroid involvement in TB is unknown, with the following possible explanations: bactericidal thyroid gland colloid action, extremely high thyroid blood flow, increased phagocyte activity in hyperthyroidism, and antituberculous action of the thyroid hormone $(6,9)$. The TB bacillus reaches the thyroid through hematogenous and limphogenous 


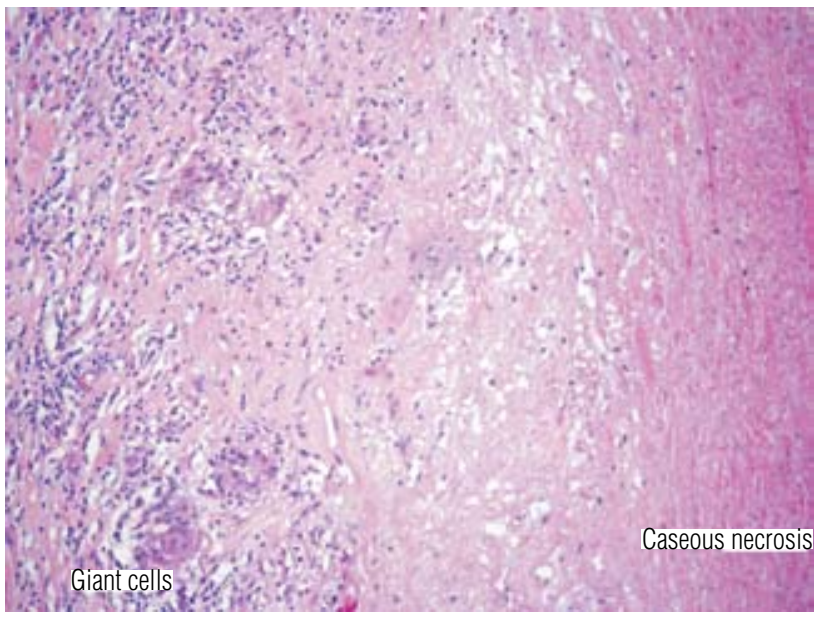

A

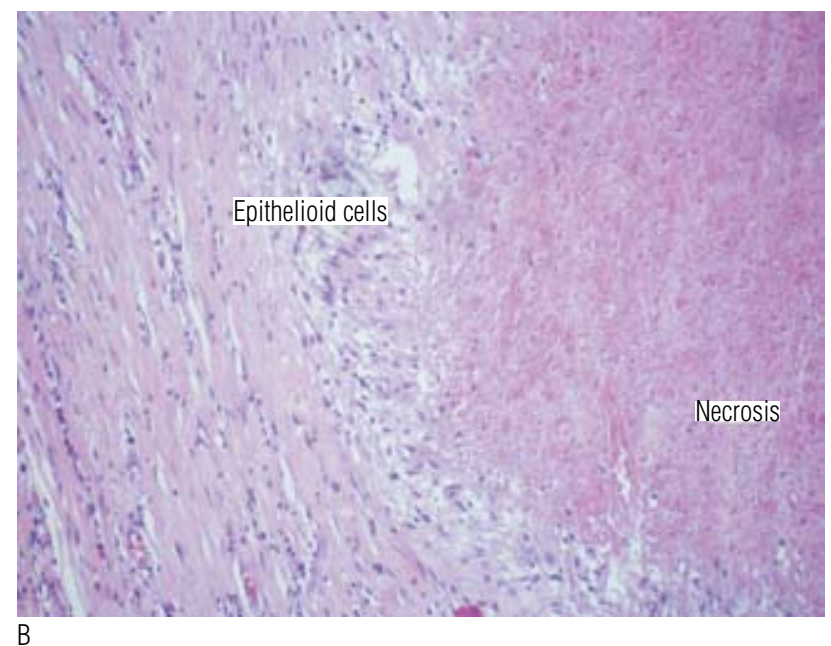

B

Figure 1. (A) Epithelioid granulomas with central caseous necrosis, epithelioid cells around, some lymphocytes and fibrosis at the periphery; (B) granulomatous inflammation process with central caseous necrosis, epithelioid and scarce giant cells and a lymphocyte halo at the periphery

dissemination or directly by cervical lymphadenitis. Microscopically, there is destruction of thyroid tissue by tuberculous granuloma $(3,6)$.

The histopathological aspect of the disease varies depending upon the patient immunity. The disease may present as multiple granulomatous foci throughout the gland or miliary TB, or as a mass with caseous necrosis simulating a goiter with abscess formation, or even as a chronic granulomatous process with fibrosis of the gland. The differential diagnosis of the histological picture should be done with sarcoidosis and subacute (giant cells) thyroiditis $(3,8,9)$. Many cases of primary thyroid TB reported at the beginning of the $20^{\text {th }}$ century had characteristics of giant cell thyroiditis (4), a fact later reassessed in the literature (10). The three criteria for diagnosis of TB in the thyroid, described by Seed, in 1939 included: presence of acid-fast bacilli, necrosis or abscess in the gland and tuberculous focus outside the thyroid (not essential criterion) $(2,4,6)$. The usual result of the involvement of the thyroid is focal caseous TB, presenting as localized swelling, cold abscess, nodule with or without cystic component, multinodular goiter and - more rarely - as acute abscess, possibly confused with carcinoma $(9,11)$. Fibrosis associated with $\mathrm{TB}$ is described and adherence to the underlying tissue can cause dysphagia and dyspnea $(2,6)$.

Eventually, the patient may be asymptomatic (9). The clinical presentation may be acute by abscess or thyroiditis, but is often subacute. The duration of symptoms varies from two weeks to one year, with reports of dysphagia, dyspnea and dysphonia due to paralysis of laryngeal nerve. The thyroid affected is increased in volume, hard consistency, adhered to the underlying tissues $(2,3)$. The thyroid function is preserved in the vast majority of cases reported (10) and the description of cases with thyroid hormones abnormalities is extremely rare (9). The description of thyrotoxicosis, generally at the beginning of glandular involvement, is reported as "a clinical syndrome of hyperthyroidism" since the beginning of the last century $(2,12)$. The hypothyroidism is caused by extensive glandular destruction by caseous necrosis $(3,6)$. In recent review of the literature, only one case of hypothyroidism due to thyroid $\mathrm{TB}$ was reported $(9,13)$.

Furthermore, the ultrasonographical findings includes a heterogeneous mass or multiple hypoechoic lesions in the thyroid associated with cervical lymph node enlargement; the computed tomography may reveal suggestive image of abscess with increased peripheral density $(2,14)$. As a diagnostic method, the FNA can be effective and confirm the presence of TB in the thyroid, through collecting material for baciloscopy and culture $(7,9)$. Polymerase chain reaction analysis to detect DNA of Mycobaterium tuberculosis can be done in the cytology material $(3,4)$.

The preoperative diagnosis is rare and it is usually made after surgical resection of the lesion. The treatment of choice is based on surgery and anti-TB drugs administration $(8,9)$. Since the diagnosis is difficult to be performed before surgery and considering the differential diagnosis of cancer, most cases are treated with thyroidectomy (2). The preoperative diagnosis allows 
more limited surgical approach, such as abscess drainage $(3,15)$. The use of anti-TB drugs is the basis of thyroid TB treatment and its effectiveness does not differ in relation to other organ sites of involvement of TB $(9,15)$.

In retrospect, the medical history of this patient suggested thyroid TB in the differential diagnosis (multiple negative FNA and negative frozen section), except for the rapid thyroid mass enlargement, multiple left neck nodes and left vocal cord paralysis (all symptoms resembling thyroid carcinoma). However, like the usual literature, the diagnosis was made only with the histopathological examination. Additionally, three months before the complaints of enlargement of the thyroid, the patient had developed primary hypothyroidism, presented with undetectable serum levels of antithyroperoxidase and antithyroglobulin antibodies, without thyroid lymphocytic infiltration in the cytological and histopathological specimens, facts that point out to non-autoimmune cause of gland dysfunction. Thus, the primary hypothyroidism is due to destruction of the thyroid parenchyma by $\mathrm{TB}$ infectious process, which is rarely reported in the literature. Clinical, laboratorial and radiological approaches followed the steps described in the literature, and the treatment succeeded by thyroidectomy and administration of anti-TB drugs.

In conclusion, $\mathrm{TB}$ in the thyroid is not frequent, but should be considered as differential diagnosis of anterior cervical mass with acute or subacute growth. The diagnosis can be achieved through cytology by FNA, but generally it is reached after surgical resection of the lesion and pathological examination. The treatment is based on surgery and anti-TB drug administration. Additionally, hypothyroidism associated with primary thyroid TB is rare, but it could be seen in suggestive cases.
Disclosure: no potential conflict of interest relevant to this article was reported.

\section{REFERENCES}

1. Bates JH, Stead WW. The history of tuberculosis as a global epidemic. Med Clin North Am. 1993;77(6):1205-17.

2. Simkus A. Thyroid tuberculosis. Medicina (Kaunas). 2004;40(3): 201-4.

3. Terzidis K, Tourli P, Kiapekou E, Alevizaki M. Thyroid tuberculosis. Hormones. 2007;6(1):75-9.

4. Ghosh A, Saha S, Bhattacharya B, Chattopadhay S. Primary tuberculosis of thyroid gland: a rare case report. Am J Otolaryngol. 2007;28(4): 267-70.

5. Pazaitou K, Chrisoulidou A, Ginikopoulou E, Angel J, Destouni C, Vainas I. Primary tuberculosis of the thyroid gland: report of three cases. Thyroid. 2002;12(12):1137-40.

6. Tan KK. Tuberculosis of the thyroid gland - A review. Ann Acad Med Singapore. 1993;22(4):580-2.

7. Mondal A, Patra DK. Efficacy of fine needle aspiration cytology in the diagnosis of tuberculosis of the thyroid gland: a study of 18 cases. J Laryngol Otol. 1995;109(1):36-8.

8. Khan EM, Haque I, Pandey R, Mishra SK, Sharma AK. Tuberculosis of the thyroid gland: a clinicopathological profile of four cases and review of the literature. Aust N Z J Surg. 1993;63(10):807-10.

9. Bulbuloglu E, Ciralik E, Okur E, Ozdemir G, Ezberci F, Cetinkaia A. Tuberculosis of thyroid gland: review of literature. World J Surg. 2006;30(2):149-55.

10. Goldfarb H, Schifrin D, Graig F. Thyroiditis caused by tuberculous abscess of the thyroid gland. Case report and review of the literature. Am J Med. 1965;38:825-8.

11. Surer I, Ozturk $\mathrm{H}$, Cetinkursun $\mathrm{S}$. Unusual presentation of tuberculosis reactivation in childhood: an anterior neck mass. J Pediatric Surg. 2000;35(8):1263-5.

12. Rankin FW, Graham A. Tuberculosis of thyroid gland. Ann Surg. 1932;96(4):625-48.

13. Barnes $P$, Weatherstone R. Tuberculosis of thyroid: two case reports. Br J Dis Chest. 1979;73(2):187-91.

14. Kang BC, Lee SW, Shim SS, Choi HY, Baek SY, Cheon YJ. US and CT findings of tuberculosis of the thyroid gland: three case reports. Clin Imaging. 2000;24(5):283-6.

15. El Malki HO, Mohsine R, Benkhraba K, Amahzoune M, Benkabbou A, El Absi M, et al. Thyroid tuberculosis: diagnosis and treatment. Chemotherapy. 2006;52(1):46-9. 